\title{
How are Buying Intentions in a Marketplace Formed? An acceptance of New Technology in Young People
}

\author{
Bryan Julio ${ }^{1}$, Dudi Anandya ${ }^{2 *}$, Indarini $^{3}, \&$ Freddy Mutiara ${ }^{4}$
}

\author{
${ }^{1}$ University of Surabaya, Surabaya, Indonesia \\ ${ }^{2}$ University of Surabaya, Surabaya, Indonesia \\ ${ }^{3}$ University of Surabaya, Surabaya, Indonesia \\ ${ }^{4}$ University of Surabaya, Surabaya, Indonesia \\ *Corresponding author. Email: dudi@staff.ubaya.ac.id
}

\begin{abstract}
This research discusses the existing marketplaces in Indonesia. The purpose of this research is to determine the effects of Social Influence on Behavioral Intention and Perceived Usefulness on Attitude in a marketplace. This study is quantitative research with a causal design, with 304 respondents from Surabaya. There are 9 variables in this study, namely Perceived Usefulness (PU), Perceived Enjoyment (PE), Perceived ease of use (PEOU), Trust in the mvendor (TR), Social influences (SI), Satisfaction (SAT), Usage behavior (USE), Behavioral intention (BI), and Attitude (ATT). The results show that Social Influence has a positive effect on Behavioral Intention, while Perceived usefulness is not proven to affect Attitude.

Keywords: social influence, behavioral intention, perceived usefulness, attitude.
\end{abstract}

\section{INTRODUCTION}

Today, people love an efficient lifestyle, including the shopping method. Previously, shopping has to be done by face-to-face transaction, where consumers need to find a store and items needed. These days, people can search for items they want only through gadgets by visiting various mobile stores. According to CNBC Indonesia, even though the world is fighting the Covid-19 pandemic, e-commerce in Indonesia is growing. Bank Indonesia reported that e-commerce transactions jumped to the US \$ 2.4 billion, an increase of $26 \%$ from the second quarter of 2019. Innovations occur as digital payments gradually shift conventional methods. This facilitates e-commerce transactions so that the year-on-year increase in April 2020 was $7 \%$, and the volume was up $78 \%$ (Citradi 2020)

Mobile commerce has several definitions. According to Pradhan (2003), mobile commerce refers to the purchase and sale of goods and services through wireless handheld devices such as mobile telephones (cellular phones), personal data assistants (PDAs), mp3 players, digital cameras, handheld gaming devices, and computers. On the other hand, Fuady (2002) instead of Pradhan (2003) defines e-commerce as a business process using electronic technology that connects companies, consumers, and society in electronic transactions. Both definitions agree that mobile commerce involves electronic transactions through a device.

Research on the intention to use e-commerce in Indonesia is very urgent given the very high growth of users. This study aims to help determine what factors can influence behavioral intention and attitude in a marketplace. The benefits of this research are expected to provide information for business actors regarding consumer responses to what factors can increase behavioral intention and attitude in a marketplace. 


\subsection{Effect of attitude on behavioral intention}

In this research, attitude characterizes a person's evaluation of certain behaviors, and it is assumed that a favorable evaluation will form an intention to use an information technology system (for example, shopping), while on the other hand, a poor evaluation will prevent a person from using it (Verma \& Sinha 2018). Groß (2018) states that attitude has an effect on Behavioral Intention; thus we propose a hypothesis: H1: Attitude has a positive effect on behavioral in- tension.

\subsection{Effect of behavioral intention on usage behavior}

Behavioral Intention refers to the willingness to per- form certain behavioral tasks without any action being taken, while Usage Behavior refers to the use behavior itself (Groß 2018). Groß (2018) states that behavioral intention affects usage behavior. Based on this understanding, we propose a hypothesis:

$\mathrm{H} 2$ : Behavioral intention has a positive effect on usage behavior.

\subsection{Effect of perceived usefulness on attitude}

Behavioral Groß (2018) states that Perceived Usefulness affects attitude. Perceived usefulness itself is associated with the benefits offered by m-shopping and refers to utilitarian shopping values (e.g., allowing shopping at any time and place; with permanent and convenient internet access, offering a choice of information, goods, and unlimited services; and offering real-time interaction and communication channels to connect with all colleagues and vendors) (Pantano \& Priporas 2016 instead of Groß 2018). Thus, we propose the following hypothesis:

H3: Perceived usefulness has a positive effect on attitude.

\subsection{Effect of perceived enjoyment on attitude}

Perceived enjoyment focuses on activities that involve multisensory and emotive experiences in the consumption process during $\mathrm{m}$-shopping; thus, perceived enjoyment satisfies entertainment and recreational needs in managing functionally oriented purchase results (supporting time or good value for money) (Kim et al. 2015 instead of Tyas \& Darma 2017). Groß (2018) reveals that perceived enjoyment has an effect on attitude, thus we propose the following hypothesis:

H4: Perceived enjoyment has a positive effect on attitude.

\subsection{Effect of perceive ease of use on perceive usefulness}

Groß (2018) argues that perceived ease of use has an effect on perceived usefulness. Another important attitude factor for determining $\mathrm{m}$-shopping acceptance is ease of use (PEOU). This is related to the extent to which one believes that using a particular mshopping service will be free of mental and/or physical effort and the level of effort in learning to use m-shopping services properly (Groß 2018). The easier the system's ease of use, the higher the users' perceived usefulness.

H5: Perceived ease of use has a positive effect on perceived usefulness.

\subsection{Effect of perceived ease of use on perceive usefulness}

Groß (2018) states that perceived ease of use affects perceived enjoyment. The more accessible and more intuitive the m-shop uses a smartphone, the more valuable and fun it will be (Kim et al. 2015 instead of Tyas \& Darma 2017). Complexity and lack of usability will have the opposite effects, forming negative attitudes based on experiences of minor usability and pleasure; as a result, preventing consumers from regularly engaging in m-shopping (Sharifi \& Esfidani 2014). The hypothesis proposed is as follows: 
H6: Perceived ease of use has a positive effect on perceived enjoyment.

\subsection{Effect of perceived ease of use on attitude}

Groß (2018) states that perceived ease of use has an effect on attitude. The ease of use of perception is one of the factors in the TAM model that has been tested by Davis et al. (1989) instead of Groß (2018) . These results indicate that these factors are proven to explain a person's reasons for using information systems and indicate that users accept the new systems being developed.

H7: Perceived ease of use has a positive effect on attitude.

\subsection{Effect of trust in the m-vendor on behavioral intention}

Groß (2018) stated that trust in the m-vendor has an effect on behavioral intention. When consumers feel confident with certain vendor specifications (for example, virtue, competence, and integrity), a positive feeling will likely be formed, and the first business activities will begin, resulting in sharing of personal information and conducting $\mathrm{m}$ purchase transactions (Yang 2015 instead of Verma \& Sinha 2018). Therefore, m-vendor trust reduces the uncertainty and complexity faced by consumers when m-shopping and helps to engage more optimistically and positively (Groß 2018).

H8: Trust in the m-vendor has a positive effect on behavioral intention.

\subsection{Effect of social influence on behavioral intention}

Groß (2018) states that Social Influence has an effect on behavioral intention. Social influence is a type of social pressure whose degree depends on the desire of individual consumers to follow the preferred reference group and norms (social desires), which eventually becomes the border for group members' uniform behavior (Yang 2015 instead of Verma \& Sinha 2018). Therefore, it is not surprising that social influence strongly influences consumers' intention to engage in m-shopping (Zhang et al. 2012 instead of Groß 2018).

H9: Social influence has a positive effect on behavioral Intention.

\subsection{Effect of satisfaction on usage behavior}

Satisfaction is considered the most important factor in determining shopping behavior in this study (Hung et al. 2012 instead of Azizah 2017). Satisfaction refers to the postutilization stage, where individual consumer expectations regarding $\mathrm{m}$-shopping serve as a basis for measuring the level of satisfaction. Groß (2018) states that satisfaction affects usage behavior.

H10: Satisfaction has a positive effect on usage behaviour.

\section{RESEARCH METHODS}

This study uses primary data to obtain data directly through respondents by distributing questionnaires online. In addition to data for model testing, respondent profile data were collected, primarily related to age and gender and the purpose of conducting online transactions with certain marketplaces. The object of this research is one of the largest marketplaces in Indonesia, given its very rapid growth.

The target population in this study are respondents who are the biggest consumers/users of the marketplace application in Surabaya. Population characteristics were respondents aged at least 18 years who have purchased products from different vendors and transacted and used various types of marketplace services in the past six months and domiciled in Surabaya.

In this study, the model testing used Structural Equation Modeling (SEM) with two steps. The first step is the measurement model, and the second step is the structural model. Data processing used SPSS 20 and AMOS 18. Before processing the data, re- 
searchers first tested the validity and reliability using SPSS 20 with a total of 30 questionnaires. The questionnaire was developed using parallel translation.

\section{RESULTS AND DISCUSSIONS}

Most of the respondents in this study were male students aged 18-24 years. The three factors that makeup attitude toward mobile shopping (Perceived ease of use (PEOU), Perceived Enjoyment (PE), and Perceived Usefulness (PU)) have adjacent mean values. All the variables mean above 3 , so it can be said that the marketplace consumer's perception of the three variables is good. The results show that consumers in Surabaya love marketplace services because it makes shopping easy, attractive, and easy to use, so consumers perceive that the marketplace is valuable. Three factors that make up the behavioral intention, namely attitude toward mobile shopping (ATT), Trust in the $\mathrm{m}$ vendor (TR), and also social influences (SI) that have an average of all variables above 3 indicating that consumer perceptions are quite good. Consumers in Surabaya tend to find marketplaces that are attractive, able to provide good service, and have good automation systems, so they tend to keep using it in the future. Usage behavior is formed by two variables: behavioral intention and satisfaction, which have a high average of above 3.

It can be said that consumers have high shopping intentions via smart phones and are satisfied with the shopping transaction method, thus making consumers continue to use marketplace services for personal purchases.

In addition, the results show that $\mathrm{H} 1, \mathrm{H} 2$, $\mathrm{H} 4, \mathrm{H} 5, \mathrm{H} 6$, and $\mathrm{H} 9$ are supported, while the hypotheses $\mathrm{H} 3, \mathrm{H} 7, \mathrm{H} 8$, and $\mathrm{H} 10$ are not supported. The first hypothesis (H1) shows the influence of attitude on behavioral intention, with a CR value of 2.282. This indicates that $\mathrm{H} 1$ is supported and in line with Groß (2018) study results. The more the consumers like a marketplace, the higher the intention to use it. Hypothesis two (H2) shows the effects of behavioral intention on usage behavior, where the $\mathrm{CR}$ value is 1.903. This indicates that $\mathrm{H} 2$ is supported and in line with Groß (2018) study results. This result explains that the higher the behavioral intention, the more often the consumers use the marketplace.

Hypothesis three (H3) shows that perceived usefulness is not proven to have an effect on attitude, with a CR value of -1.304 . This result is not in line with Groß (2018) study results. This result explains that perceived usefulness is not a factor that affects the attitude of marketplace consumers. From the overall model, it can be seen that enjoyment has an effect on attitude. It can be said that consumers like the marketplace because they feel enjoyment in its use.

Hypothesis four (H4) shows the effects of perceived enjoyment on attitude with a CR value of 1.921 , which in line with Groß (2018) study results. This result explains that the higher the consumer's perceived enjoyment, the better the attitude towards the marketplace. These results indicate that consumer attitudes are formed because they enjoy using the marketplace, which could be because of the complete product display and excellent features.

Hypothesis five (H5) shows a relationship between perceived ease of use and perceived usefulness with a CR value of 9.551 in line with Groß (2018) study results. This result explains that perceived ease of use has a positive effect on the perceived usefulness in the marketplace; the easier the marketplace features to use, the more consumers will find the marketplace useful.

Hypothesis six (H6) shows the effects of perceived ease of use on perceived enjoyment with a CR value of 9,763. This implies that H6 is supported and is in line with Groß (2018) study results. This result explains that perceived ease of use has a positive effect on the perceived enjoyment of a marketplace, where the easier it is for consumers to use, the more consumers will feel the enjoyment of a marketplace. 
Hypothesis seven (H7) shows that perceived ease of use has no effect on attitude, with a CR value of 1.613 . This indicates that H7 is not supported and not in line with Groß (2018) study results Ease of use does not directly shape consumer attitude but must form enjoyment first, then consumers will like the marketplace.

Hypothesis eight (H8) shows that trust in the $\mathrm{M}$ - vendor has no effect on behavioral intention, with a CR value of -.242. This indicates that $\mathrm{H} 8$ is not supported and is not in line with Groß (2018) study results. This result explains that Trust in the M-vendor has no effect on the behavioral intention of a marketplace. This can arise because transaction security is always prioritized in a marketplace so that customers can always trust the marketplace system.

Hypothesis nine (H9) shows a relationship between social influences and behavioral intention, where social influences have a positive effect on the behavioral intention with a $\mathrm{CR}$ value of 1.779 . This indicates that $\mathrm{H} 9$ is supported and in line with Groß (2018) study results. This result explains that social influences have a positive effect on behavioral intention, the greater the social influences, the greater the intention to use them. Hypothesis ten (H10) shows that satisfaction is not proven to have an effect on usage behavior, with a CR value of 1.498 . This indicates that $\mathrm{H} 10$ research is not supported and in line with Groß (2018) study results. This result explains that satisfaction has no effect on the usage behavior of a marketplace. This could be due to the marketplace's nature as a place for sellers and buyers to meet. As long as the transaction is successful, the customers will be satisfied with the marketplace. Yet, dissatisfaction with the goods and delivery occurs; it is addressed to the seller and the expedition, not the marketplace. If there is disappointment with one of the sellers, the buyer can look for other sellers in the marketplace, which will not affect the usage behavior.

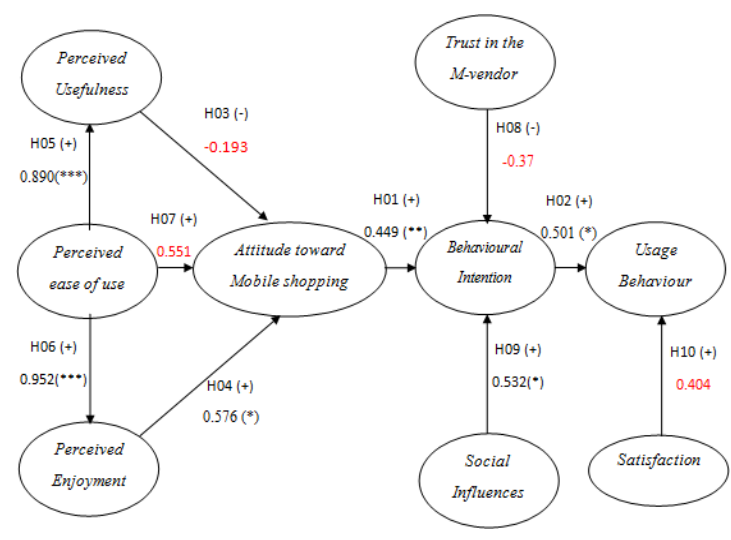

Figure 1. Hypothesis testing results.

\section{CONCLUSION}

This research provides interesting results due to the unique characteristics of marketplace users in Indonesia. Consumers emphasize the enjoyment of using a marketplace and make it a virtual storefront to browse products. Consumers also realize that they have the freedom to choose sellers, so marketplace satisfaction does not affect usage behavior.

The number of monthly active users, aka monthly active users (MAU), Tokopedia during the Covid-19 pandemic increases by 10 million more than before the pandemic to 100 million users. However, in Indonesia, Shopee has overtaken the number of Tokopedia users as the market leader for online shopping platforms. Shopee succeeded in replacing Tokopedia as the most visited ecommerce site in Indonesia in Q4 of 2019. Shopee offers enjoyment through games with prizes that can be used for shopping. Tokopedia continues to take strategic steps to strengthen its position in the Indonesian ecommerce market. Early January 2021, there was news that Gojek would merge with Tokopedia. If the consolidation of these decacorn companies can be realized, it will undoubtedly bring a competitive advantage to Tokopedia. Tokopedia will be able to complement, synergize, and improve its service portfolio from upstream to downstream in supply chains that competitors do not own. This also has the opportunity to increase To- 
kopedia's behavioral intention and usage behavior.

\section{REFERENCES}

Azizah, B. 2017. Pengaruh brand image dan brand trust ter- hadap loyalitas pelanggan melalui kepuasan pelanggan Bank Syariah di Kota Malang. Doctoral dissertation. Malang: Uni- versitas Islam Negeri Maulana Malik Ibrahim.

Citradi, T. 2020. Ramai-Ramai Orang Mendadak JadiPedagang, Tanda Apa Ini?, CNBC Indonesia. Retrieved fromhttps://www.cnbcindonesia.com/news/20200 706145351-4-170562/ramai-ramai-orangmendadak-jadi-pedagang-tanda-apa-ini.

Groß, M. 2018. Heterogeneity in consumers' mobile shopping acceptance: A finite mixture partial least squares modelling approach for exploring and characterising different shopper segments. Journal of Retailing and Consumer Service 40: 8-18.

Pradhan, S. 2003. Mobile commerce in the automobile industry. International Conference on Information Technology: Coding and Computing; Proc ITCC 2003. IEEE.

Sharifi, S.S. \& Esfidani, M.R. 2014. The impacts of rela- tionship marketing on cognitive dissonance, satisfaction, and loyalty. International Journal of Retail \& Distribution Management.

Tyas, E.I. \& Darma, E.S. 2017. Pengaruh Perceived Usefulness, Perceived Ease of Use, Perceived Enjoyment, dan Actual Usage Terhadap Penerimaan Teknologi Informasi: Studi Empiris Pada Karyawan Bagian Akuntansidan Keuangan Baitul Maal Wa Tamwil Wilayah Daerah Istimewa Yogyakarta. Reviu Akuntansi dan Bisnis Indonesia 1(1): 2535.

Verma, P. \& Sinha, N. 2018. Integrating perceived economic wellbeing to technology acceptance model: The case of mobile based agricultural extension service. Technological forecasting and social change 126: 207-216. 